\title{
Comparative Investigation of Mechanical, Tribological and Thermo- Mechanical Properties of Commonly Used 3D Printing Materials
}

\author{
Sinan Yilmaz ${ }^{1 *}$ \\ ${ }^{1 *}$ Department of Mechanical and Material Technologies, Kartepe 41180, Kocaeli, Turkey, (ORCID: 0000-0001-7107-5454), sinan.yilmaz@kocaeli.edu.tr
}

(International Conference on Design, Research and Development (RDCONF) 2021 - 15-18 December 2021)

(DOI: 10.31590/ejosat.1040085)

ATIF/REFERENCE: Yilmaz, S. (2021). Comparative Investigation of Mechanical, Thermo-Mechanical and Tribological Properties of Commonly Used 3D Printing Materials. European Journal of Science and Technology, (32), 827-831.

\begin{abstract}
In this study, it is aimed to comparatively examine tensile, thermomechanical, and adhesive wear properties of PLA (poly lactic acid), ABS (acrylonitrile butadiene styrene) and PETG (polyethylene terephthalate glycol) materials, which are the most widely used filament materials in 3D (three dimensional) printing technology. The printing process was carried out by considering the mostly preferred manufacturing parameters by the end users and the options offered by the slicing software by default. Mechanical tests were performed at three different temperatures, 25,35 and $45{ }^{\circ} \mathrm{C}$, according to the glass transition temperatures of the materials. Determination of tribological properties, both bottom and upper surfaces of the test samples were exposed to adhesive wear by using standard pin-on disc tester. During the tensile tests, it was observed that the most sensitive material in terms of the alteration of mechanical properties with temperature was PLA, and the most stable material was ABS. It was determined that there was a significant difference in wear volume for all tested materials, depending on whether the abraded surface was top or bottom. The variation of storage modulus values with temperature was also investigated by applying DMTA (Dynamic mechanic thermal analysis) tests to the samples.
\end{abstract}

Keywords: 3D printing technology, Tribology, Mechanical properties, Thermo-mechanical properties.

\section{Yaygın Kullanılan 3B Baskı Malzemelerinin Mekanik, Tribolojik ve Termo-Mekanik Özelliklerinin Karşılaştırmalı Olarak İncelenmesi}

Öz

Bu çalışmada, 3B (üç boyutlu) baskı teknolojisinde filaman malzemesi olarak en yaygın kullanılan PLA (poli laktik asit), ABS (akrilonitril bütadien stiren) ve PETG (polietilen tereftalat glikol) malzemelerinin çekme, termo-mekanik ve adhezif aşınma özelliklerinin karşılaştırmalı olarak incelenmesi amaçlanmıştır. Baskı prosesi, son kullanıcıların en çok tercih ettiği imalat parametreleri ve dilimleme yazılımının varsayılan olarak sunduğu seçenekler dikkate alınarak gerçekleştirilmiştir. Mekanik testler, malzemelerin camsı geçiş sıcaklıkları dikkate alınarak 25, 35 ve $45{ }^{\circ} \mathrm{C}$ olmak üzere üç farklı sıcaklıkta uygulanmıştır. Tribolojik özelliklerin belirlenmesi için numunelerin hem alt hem de üst yüzeyleri standart pin-on disk test cihazı kullanılarak adhezif aşınmaya maruz bırakılmıştır. Çekme testleri boyunca mekanik özelliklerin sıcaklıkla değişimi açısından en hassas malzemenin PLA, en kararlı malzemenin ise ABS olduğu gözlenmiştir. Numunelere DMTA (Dinamik Mekanik Termal Analiz) testleri uygulanarak depo modülü değerlerinin sıcaklıkla değişimi de incelenmiştir.

Anahtar Kelimeler: 3B baskı teknolojisi, Triboloji, Mekanik özellikler, Termo-mekanik özellikler.

* Corresponding Author: sinan.yilmaz@ kocaeli.edu.tr 


\section{Introduction}

Thanks to the rapid development of 3D printing technologies, everyday citizens may be able to fabricate products that they need for their own use instead of purchasing from traditional manufacturers. In addition, they will also develop their own designs. This causes the 3D printing method to spread to homes rather than only being used in engineering applications and a large market. As a result of this new trend, the economic size and growth rate of this sector draws attention in recent years. Research shows that in 2016 alone, the size of global consumption for 3D printing machines, materials, equipment, software, and related services exceeded \$13 billion. Moreover, worldwide spending on $3 \mathrm{D}$ printing technology is projected to increase at an annual growth rate of $22.3 \%$ over the next few years. It is known that desktop 3D printer sales for 2015 alone are approximately 278,000 worldwide. And it has also been recorded that the total revenue from automotive, aerospace and defense industry applications for 2016 is approximately 6.3 billion dollars. These data are important in terms of emphasizing the future and potential of the 3D printing industry. (Dizon et al., 2018; Tymrak et al., 2014) .

$3 \mathrm{D}$ printing is a material processing technique based on melting a thermoplastic polymer filament by passing it through a hot nozzle of a certain diameter and solidifying it one layer at a time on a flat surface (bed) to obtain a computer-generated geometry. The 3D printing process first starts with the drawing of the 3D model geometry in a computer aided design (CAD) software. This generated model file is saved as STL (Stereolithography Mosaic Language) file format to be opened later in the slicer software. Then, this STL file is opened in the slicer software and the process parameters are determined to convert this $3 \mathrm{D}$ geometry to $\mathrm{G}$ codes which will be sent to the 3D printing device. (Caminero et al., 2018; Harikrishnan \& Soundarapandian, 2018; Kousiatza \& Karalekas, 2016).

Although the variety of filament materials used in $3 \mathrm{D}$ printing technology is increasing day by day, the thermoplastic materials currently used are PLA, ABS, PETG, polypropylene (PP) or polyethylene (PE). In addition, engineering thermoplastics with improved mechanical performance, such as polyamide (Nylon), polycarbonate (PC), polyetheretherketone (PEEK), polyetherimide (PEI), polyethersulfone (PES) or polyphenylene sulfide (PPS) is also possible. While traditionally ABS has been used in 3D printers for engineering applications, personal desktop printers started with ABS but shifted to PLA in time owing to its attractive properties such as eco-friendly behavior, bio-compostability, being odorless as well as low shrinkage and easy printability. (Chacón et al., 2017; Dizon et al., 2018; Song et al., 2017; Sun et al., 2008; Weng et al., 2016).

Like the filament material used, the process parameters in $3 \mathrm{D}$ printing are also a critical issue that affects the properties of fabricated products. The most important of these parameters are layer thickness, printing speed, infill ratio, melting temperature, printing orientation, printing pattern (Alafaghani et al., 2017; Mohan et al., 2017; Zou et al., 2016).

In this study, adhesive wear behavior, mechanical properties and thermomechanical properties of PLA, ABS and PETG based materials obtained by $3 \mathrm{D}$ printing technology were investigated by choosing traditional printing parameters.

\section{Material and Method}

\subsection{Sample Preparation}

All the materials tested in this study were printed on a CREALITY brand (CR-10S Pro) 3D printer using ESUN brand (PLA+, ABS+ and PETG) $1.75 \mathrm{~mm}$ diameter white color filament. $0.4 \mathrm{~mm}$ nozzle diameter, $0.2 \mathrm{~mm}$ layer thickness, $30 \%$ infill ratio, raster angle $45^{\circ}$ and $\mathrm{XYZ}$ orientation were considered while creating the STL files obtained from the Ultimaker Cura (Version 4.12.1) software. Other parameters were set to be the software's default values. Nozzle and heating bed temperatures were chosen as 205 and $60{ }^{\circ} \mathrm{C}$ for PLA, 240 and $80{ }^{\circ} \mathrm{C}$ for ABS, 240 and $80{ }^{\circ} \mathrm{C}$ for PETG, respectively.

\subsection{Characterization Methods}

Differential Scanning Calorimetry (DSC) analysis was applied using the Mettler Toledo DSC 1 analyzer at a ratio of 5 ${ }^{\circ} \mathrm{C} / \mathrm{min}$ from 25 to $198{ }^{\circ} \mathrm{C}$ in a nitrogen atmosphere to determine the glass transition temperatures of $3 \mathrm{D}$ printed materials.

To obtain mechanical properties of the materials, dumbbell shape specimens with gauge length of $50 \mathrm{~mm}$, width $4 \mathrm{~mm}$ and thickness $2 \mathrm{~mm}$ were tested by using a Shimadzu AGX (with a temperature control cabinet) tensile testing machine at various temperatures, according to ISO 527 (Norm, 2002). The average values of tensile stress, tensile strain, and tensile modulus from at least five tests, where the crosshead speed fixed at $5 \mathrm{~mm} / \mathrm{min}$. was considered.

Dynamic Mechanic Thermal Analysis (DMTA) tests were conducted to the $4 \times 25 \times 2 \mathrm{~mm}^{3}$ rectangular shape specimens in a bending mode at a frequency of $1 \mathrm{~Hz}$ with a healing rate of 5 ${ }^{\circ} \mathrm{C} /$ min by using a TA Instruments DMA Q800. Change of storage modulus versus temperature was recorded.

A hardened steel ball with a radius of $3 \mathrm{~mm}$ pressed onto surfaces of $16 \times 16 \mathrm{~mm}^{2}$ test samples using a pin-on disc device (Nanovea Tribometer) for a sliding distance of $150 \mathrm{~m}$ and $10 \mathrm{~N}$ normal force. The radius of the point (friction radius) where the steel sphere touches the samples on the rotating disk was set as 5 $\mathrm{mm}$. The coefficient of friction (COF) values, along the sliding distance, at the contact point of the steel ball were calculated and recorded by the tester. A light microscope was used to measure wear traces of the samples and wear volumes were calculated considering the following equation (ASTM G99-05) by assuming that the wear of the ball is negligible (AguileraCamacho et al., 2015)

$V=\frac{\pi \times R \times D^{3}}{6 \times r}$

where $V$ is the wear volume $\left(\mathrm{mm}^{3}\right) ; R$ is the friction radius $(\mathrm{mm}) ; D$ is the wear trace width $(\mathrm{mm})$; and $r$ is the ball radius $(\mathrm{mm})$. Then following equation was used to calculate wear rates of the materials

$$
k=\frac{V}{L \times X}
$$

where $V$ is the wear volume $\left(\mathrm{mm}^{3}\right), L$ is the load $(\mathrm{N}), X$ is the sliding distance $(\mathrm{m})$ and $k$ is the wear rate $\mathrm{mm}^{3} / \mathrm{Nm}$ ) (Kane et al., 2010) 


\section{Results and Discussion}

\subsection{Thermal Properties}

It is important to know the thermal transition temperatures to predict the performance of materials at different temperatures. Thus, DSC analyzes were performed on the materials to determine the tensile test temperatures applied in this study and the curves obtained are presented in Fig. 1. Looking at the glass transition temperature $\left(T_{g}\right)$ values marked on the curves in the figure, it was seen that the material with the lowest temperature was PLA, and therefore $45{ }^{\circ} \mathrm{C}$ was chosen as the maximum tensile test temperature. In addition, these glass transition temperature values were found to be compatible with the values provided by the manufacturer.

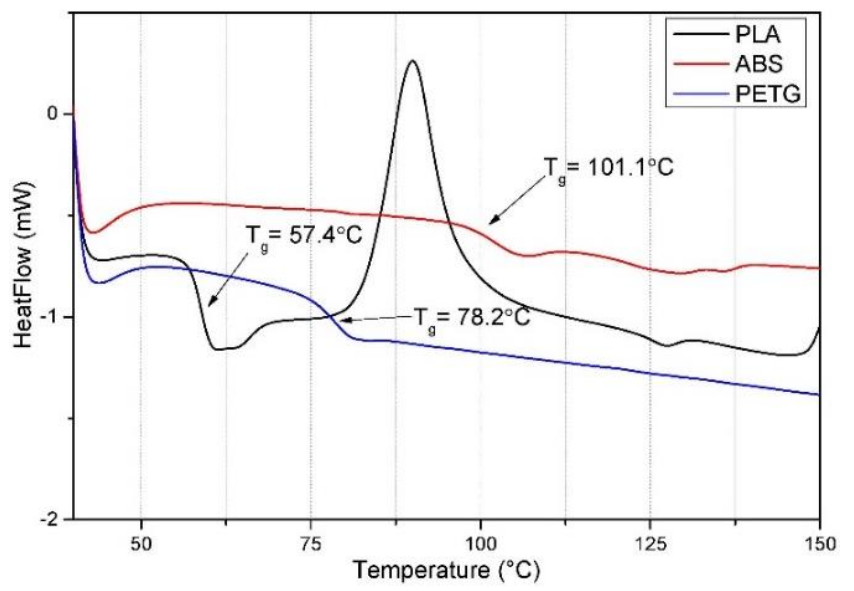

Figure 1. DSC curves of the materials

\subsection{Dynamic-Mechanic Thermal Behavior}

Storage modulus $\left(E^{\prime}\right)$ curves of PLA, ABS and PETG for different temperature ranges are given in Fig. 2. As the name suggests, $E^{\prime}$ is a measure of the amount of energy stored and is used to express the stiffness of a material (Karsli et al., 2016). It is seen that the $E^{\prime}$ for PLA decreases rapidly after about $50{ }^{\circ} \mathrm{C}$ although it has the highest value at low temperatures in given range compared to the other materials.

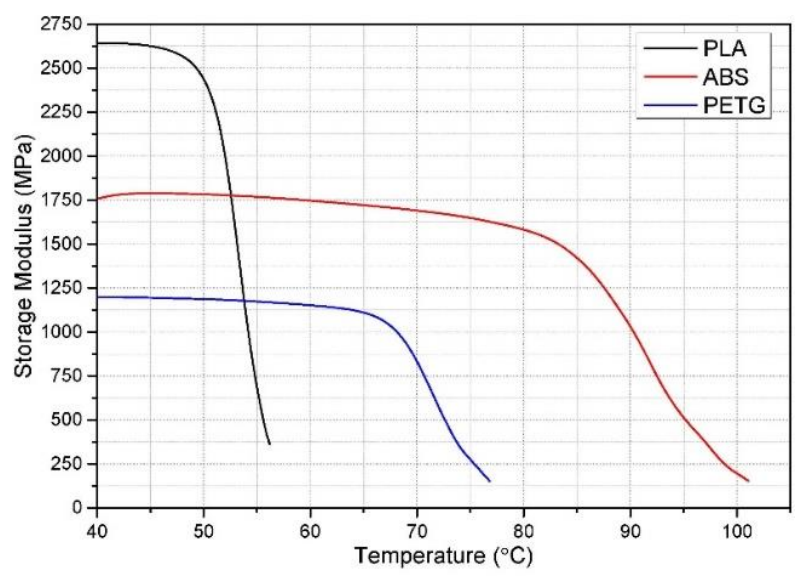

Figure 2. Storage modulus versus temperature

\subsection{Mechanical Properties}

The tensile test samples are abbreviated according to test temperatures. For example, PLA_45 indicates that test was conducted to the sample at $45{ }^{\circ} \mathrm{C}$. At least 3 specimens were tested for each temperature value and the samples were kept in the cabinet for $5 \mathrm{~min}$. before the test.

e-ISSN: 2148-2683
The mean values of yield strength $\left(\sigma_{y}\right)$, tensile modulus $(E)$ and elongation at break $(\varepsilon)$ obtained from tensile tests at various temperatures for each material are presented in Fig. 3 and listed in Table 1. When the curves in Fig. 3(a) are examined, it is seen that while the strength and modulus values decrease with increasing temperature for PLA, the elongation at break value increases significantly. In addition, as it can be seen from Fig. 3 (b), the alteration in mechanical properties was very limited at the chosen test temperatures for ABS. Considering the curves plotted for PETG in Fig. 3(c), it is seen that the elongation at break increases significantly without a significant decrease in strength and especially modulus. The reason for these different mechanical behaviors is the proximity of the test temperatures to the glass transition temperature of the materials. Furthermore, this result is consistent with the curves of the storage modulus in Fig. 2.

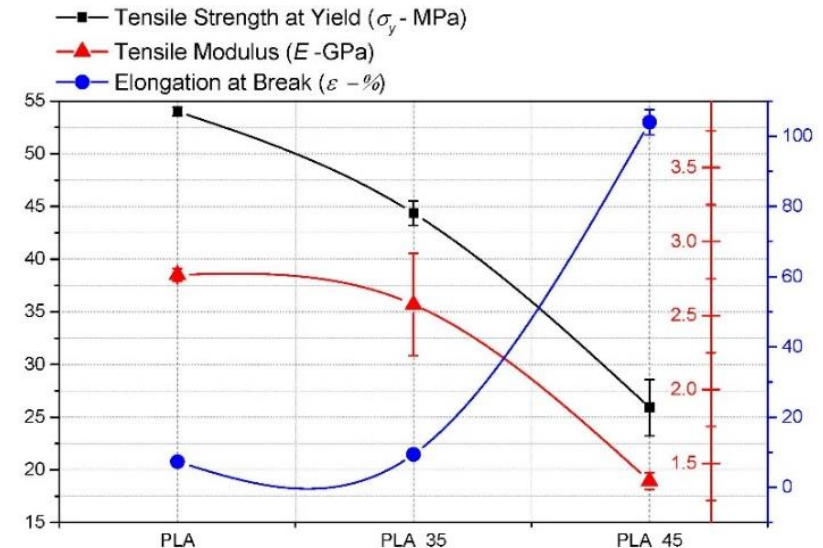

(a)

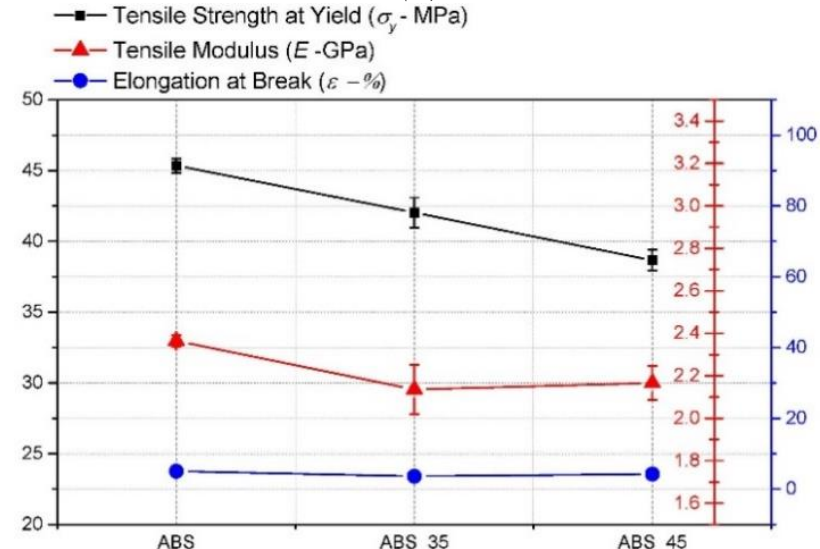

(b)

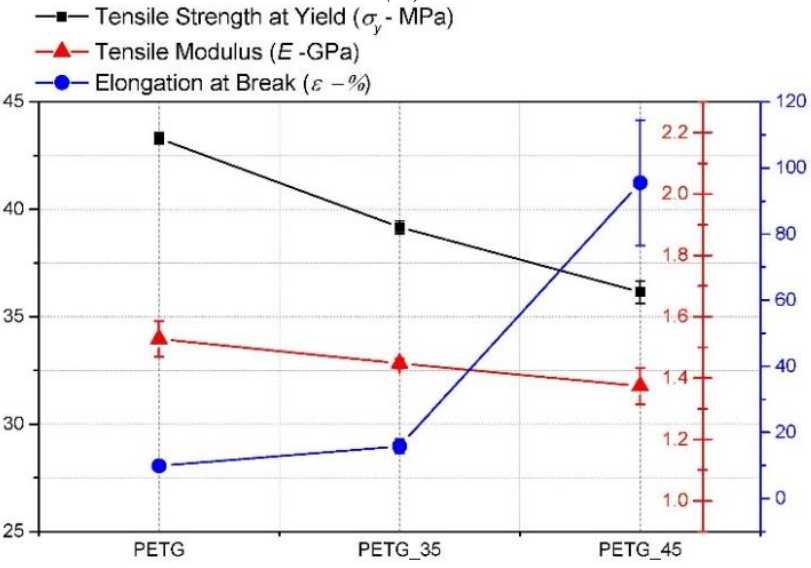

(c)

Figure 3. Alteration of tensile properties with test temperatures; a) PLA, b) ABS, c) PETG 
Table 1. Tensile properties of the materials

\begin{tabular}{l|l|l|l}
\hline \multicolumn{1}{l}{ Material } & $\boldsymbol{\sigma}_{\boldsymbol{y}}(\mathbf{M P a})$ & $\boldsymbol{E}(\mathbf{G P a})$ & $\boldsymbol{\varepsilon}(\boldsymbol{\%})$ \\
\hline PLA & $54.0 \pm 0.4$ & $2.8 \pm 0.0$ & $7.3 \pm 0.2$ \\
PLA_35 & $44.4 \pm 1.1$ & $2.6 \pm 0.3$ & $9.4 \pm 0.1$ \\
PLA_45 & $25.9 \pm 2.7$ & $1.4 \pm 0.1$ & $104.0 \pm 3.6$ \\
ABS & $45.4 \pm 0.5$ & $2.4 \pm 0.0$ & $5.0 \pm 0.4$ \\
ABS_35 & $42.0 \pm 1.1$ & $2.1 \pm 0.1$ & $3.6 \pm 0.4$ \\
ABS_45 & $38.7 \pm 0.7$ & $2.2 \pm 0.1$ & $4.2 \pm 0.2$ \\
PETG & $43.3 \pm 0.3$ & $1.5 \pm 0.1$ & $9.9 \pm 1.2$ \\
PETG_35 & $39.2 \pm 0.3$ & $1.4 \pm 0.0$ & $15.8 \pm 2.1$ \\
PETG_45 & $36.1 \pm 0.5$ & $1.4 \pm 0.1$ & $95.6 \pm 18.9$ \\
\hline
\end{tabular}

\subsection{Adhesive Wear Behavior}

The surface properties of the test samples obtained by the 3D printing method are different due to the nature of the method. Because the surface in contact with the heating bed can be rougher or smoother than the top with the effect of printing parameters. For this reason, there are differences in the wear behavior of these surfaces. Thus, the adhesive wear test samples are abbreviated according to which side the tested surfaces are. The letter B used in the abbreviation of the wear samples indicates the bottom, the side that contacts the heating bed, while the letter $\mathrm{T}$ denotes the top, the finishing layer.

Alteration of the friction coefficient with respect to the sliding distance for each material are presented in Fig. 4. It is seen from the Fig. 4 that the friction characteristic is different for each material depending on which side the abraded surface is on. For PLA, the friction characteristics up to a sliding distance of $50 \mathrm{~m}$ are almost the same, but then the friction coefficient on the bottom surface increases distinctly. On the other hand, there is a shift in the friction coefficient after a sliding distance of $75 \mathrm{~m}$ in ABS. For PETG, the situation is completely different, as the wear coefficient of the top surface remained almost constant throughout the test, but the wear coefficient of the bottom surface climbed up to the sliding distance of $40 \mathrm{~m}$, then stabilized. The realization of these different scenarios is since many factors such as surface smoothness, surface hardness, the effect of heat released during friction on the material are different.

Average values obtained from the wear test results, in which 5 samples were tested for each parameter, were used to calculate the wear rate by using Eq. 1 and Eq. 2. The calculated values are presented in Fig. 5 and listed in Table 2. It is seen that the test surface has a significant effect on the wear rate as well as the friction coefficient for all the materials. When the materials with abraded bottom surfaces are compared, it is seen that the wear rate of PLA is significantly higher than other materials, but it is close to each other for the top surfaces. Because PLA is the material for which the test surface has the greatest effect on the wear rate. The reason for this situation may be that the bottom surface, which is the first layer, is in constant contact with the heating plate and has lower surface hardness due to its slow cooling. In addition, it is seen that the material exhibiting the highest wear performance for both wear surfaces is PETG. This finding shows that the wear rate is not directly related to the coefficient of friction, as the coefficient of friction of PETG for the bottom surface was greater than that of ABS.

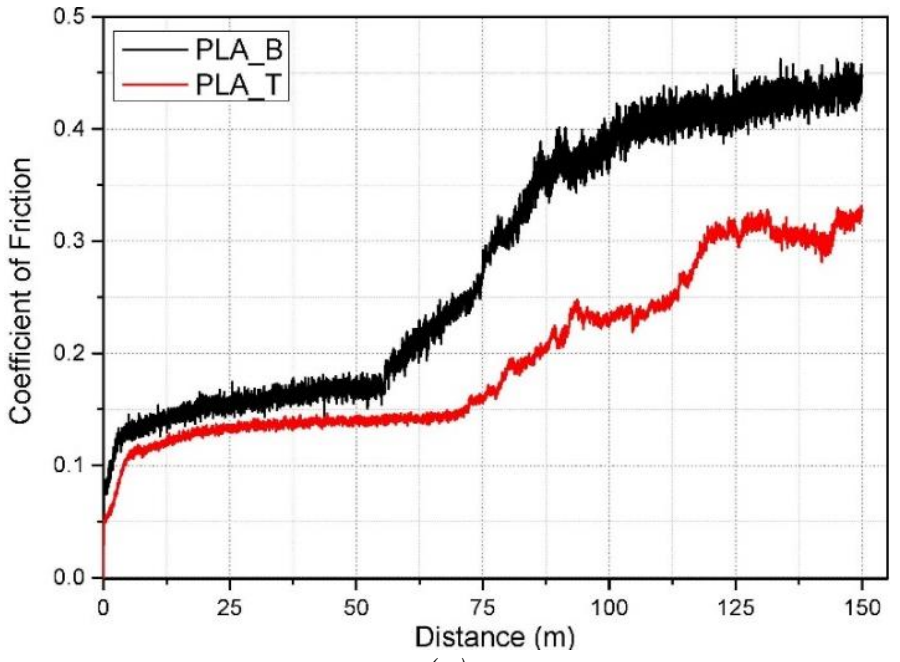

(a)

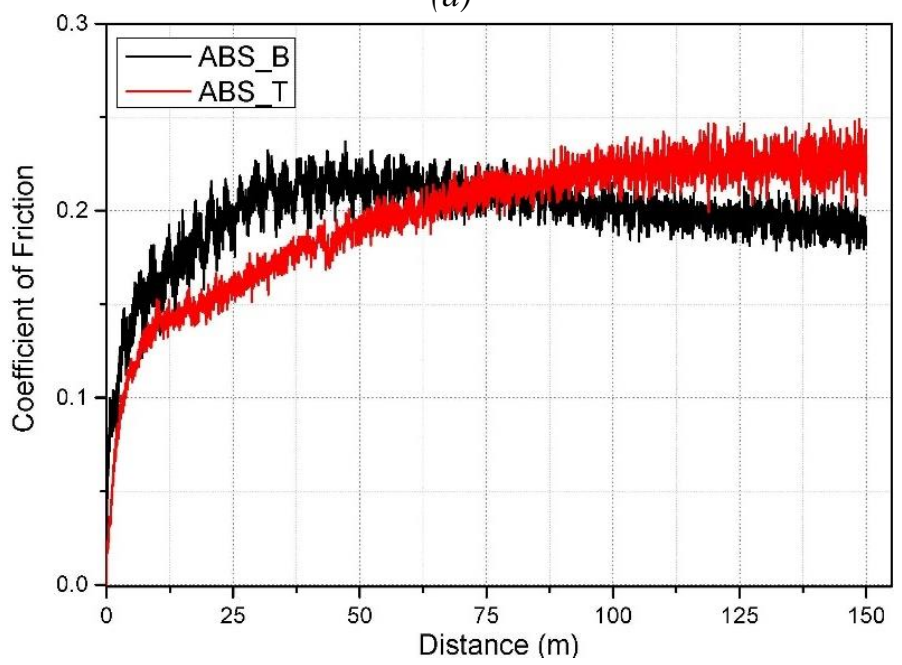

(b)

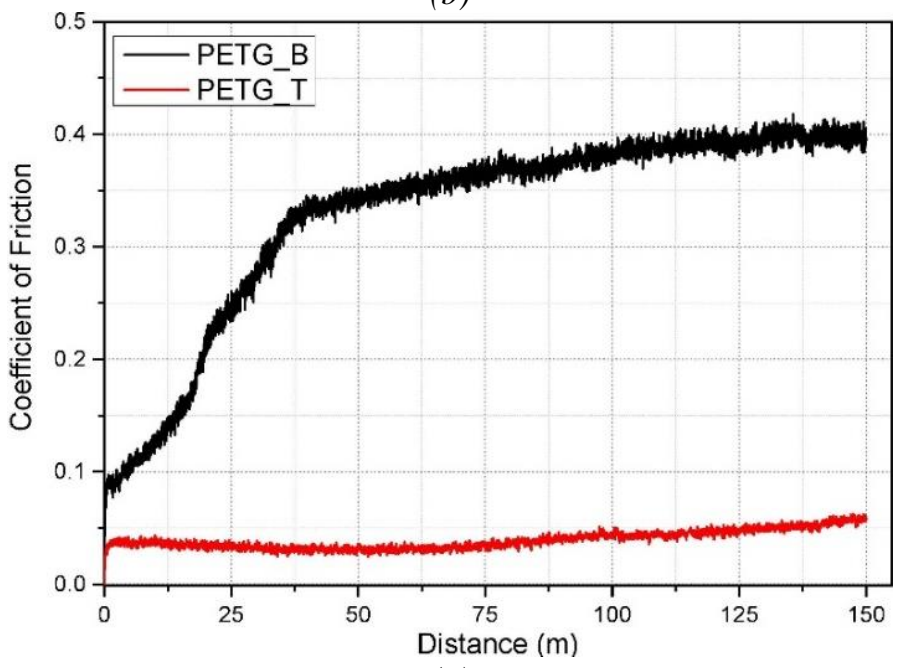

(c)

Figure 4. Coefficient of friction versus sliding distance for bottom and top surfaces; a) PLA, b) ABS, c) PETG

Table 2. Wear rates of the materials

\begin{tabular}{l|l|l|l|l|l|l}
\cline { 2 - 6 } & \multicolumn{2}{c|}{ PLA } & \multicolumn{2}{c|}{ ABS } & \multicolumn{2}{c}{ PETG } \\
& Bottom & Top & Bottom & Top & Bottom & Top \\
\hline Wear Rate & 35.1 & 4.9 & 17.5 & 3.7 & 15.3 & 1.6 \\
$x 10^{-5}$ & \pm 1.7 & \pm 0.4 & \pm 4.3 & \pm 1.8 & \pm 1.4 & \pm 1.3 \\
$\left(\mathrm{~mm}^{3} / \mathrm{Nm}\right)$ & & & & & & \\
\hline
\end{tabular}

830 


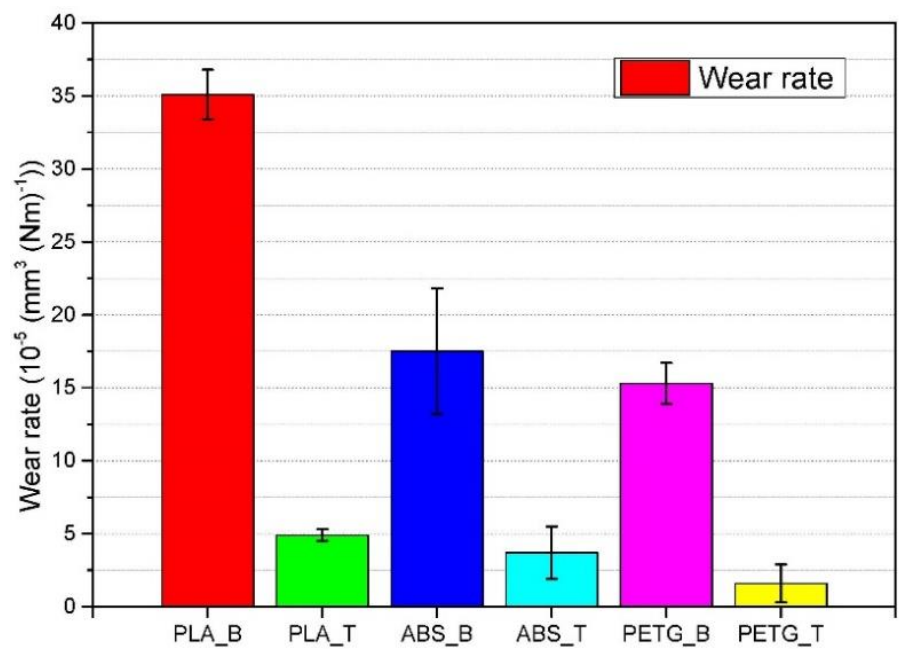

Figure 5. Wear rates of the materials for bottom and top surfaces

\section{Conclusions and Recommendations}

Mechanical, thermal, thermo-mechanical and adhesive wear properties of PLA, ABS and PETG based test samples obtained by $3 \mathrm{D}$ printing technology were investigated. Tensile test results demonstrated that the PLA is the material that exhibits the most sensitive behavior to varying test temperatures. It was found that the tensile strength and modulus of PLA significantly decreased with increasing test temperature. In addition, it was determined that the material that was least affected by the changing test temperatures in the tensile tests was ABS. It has been revealed that there is a significant difference in the adhesive wear behavior of the materials obtained by $3 \mathrm{D}$ printing in case the abraded surface is on the bottom or top side. It has been seen that the material that has the greatest effect on the wear rate of the test surface is PLA. In addition, it has been determined that the material with lowest wear performance for all wear surfaces is PLA. Finally, it was found that the material with the highest adhesive abrasion resistance was PETG.

\section{References}

Aguilera-Camacho, L. D., Hernández-Navarro, C., Moreno, K. J., García-Miranda, J. S., \& Arizmendi-Morquecho, A. (2015). Improvement effects of $\mathrm{CaO}$ nanoparticles on tribological and microhardness properties of PMMA coating. Journal of Coatings Technology and Research, 12(2), 347-355. https://doi.org/10.1007/s11998-014-9639-y

Alafaghani, A., Qattawi, A., Alrawi, B., \& Guzman, A. (2017). Experimental Optimization of Fused Deposition Modelling Processing Parameters: A Design-for-Manufacturing Approach. Procedia Manufacturing, 10, 791-803. https://doi.org/10.1016/j.promfg.2017.07.079

Caminero, M. A., Chacón, J. M., García-Moreno, I., \& Rodríguez, G. P. (2018). Impact damage resistance of 3D printed continuous fibre reinforced thermoplastic composites using fused deposition modelling. Composites Part B: Engineering, 148(April), 93-103. https://doi.org/10.1016/j.compositesb.2018.04.054

Chacón, J. M., Caminero, M. A., García-Plaza, E., \& Núñez, P. J. (2017). Additive manufacturing of PLA structures using fused deposition modelling: Effect of process parameters on mechanical properties and their optimal selection. Materials and Design, 124,

https://doi.org/10.1016/j.matdes.2017.03.065

Dizon, J. R. C., Espera, A. H., Chen, Q., \& Advincula, R. C. (2018). Mechanical characterization of 3D-printed polymers. Additive Manufacturing, 20, 44-67. https://doi.org/10.1016/j.addma.2017.12.002

Harikrishnan, U., \& Soundarapandian, S. (2018). Fused Deposition Modelling based Printing of Full Complement Bearings. Procedia Manufacturing, 26, 818-825. https://doi.org/10.1016/j.promfg.2018.07.102

Kane, S. R., Ashby, P. D., \& Pruitt, L. A. (2010). Characterization and tribology of PEG-like coatings on UHMWPE for total hip replacements. Journal of Biomedical Materials Research - Part A, 92(4), 1500-1509. https://doi.org/10.1002/jbm.a.32484

Karsli, N. G., Demirkol, S., \& Yilmaz, T. (2016). Thermal aging and reinforcement type effects on the tribological, thermal, thermomechanical, physical and morphological properties of poly(ether ether ketone) composites. Composites Part B: Engineering, 88, 253-263. https://doi.org/10.1016/j.compositesb.2015.11.013

Kousiatza, C., \& Karalekas, D. (2016). In-situ monitoring of strain and temperature distributions during fused deposition modeling process. Materials and Design, 97, 400-406. https://doi.org/10.1016/j.matdes.2016.02.099

Mohan, N., Senthil, P., Vinodh, S., \& Jayanth, N. (2017). A review on composite materials and process parameters optimisation for the fused deposition modelling process. Virtual and Physical Prototyping, 12(1), 47-59. https://doi.org/10.1080/17452759.2016.1274490

Norm, D. E. (2002). Plastics-Determination of tensile properties - Norme ISO 527-3. 1107.

Song, Y., Li, Y., Song, W., Yee, K., Lee, K. Y., \& Tagarielli, V. L. (2017). Measurements of the mechanical response of unidirectional 3D-printed PLA. Materials and Design, 123, 154-164. https://doi.org/10.1016/j.matdes.2017.03.051

Sun, Q., Rizvi, G. M., Bellehumeur, C. T., \& Gu, P. (2008). Effect of processing conditions on the bonding quality of FDM polymer filaments. Rapid Prototyping Journal, 14(2), 72-80. https://doi.org/10.1108/13552540810862028

Tymrak, B. M., Kreiger, M., \& Pearce, J. M. (2014). Mechanical properties of components fabricated with open-source 3-D printers under realistic environmental conditions. Materials and Design, 58, 242-246. https://doi.org/10.1016/j.matdes.2014.02.038

Weng, Z., Wang, J., Senthil, T., \& Wu, L. (2016). Mechanical and thermal properties of ABS/montmorillonite nanocomposites for fused deposition modeling 3D printing. Materials and Design, 102, 276-283. https://doi.org/10.1016/j.matdes.2016.04.045

Zou, R., Xia, Y., Liu, S., Hu, P., Hou, W., Hu, Q., \& Shan, C. (2016). Isotropic and anisotropic elasticity and yielding of 3D printed material. Composites Part B: Engineering, 99, 506-513. https://doi.org/10.1016/j.compositesb.2016.06.009 